\title{
Optically determined sources of allochthonous organic matter and metabolic characterizations in a tropical oligotrophic river and associated lagoon
}

\author{
Daniel L. Roelke ${ }^{1}$ \\ Section of Ecology, Evolutionary Biology and Systematics, Departments of Wildlife and Fisheries Sciences, \\ and Oceanography, Texas AEM University, 2258 TAMU, College Station, Texas 77843-2258 USA \\ James B. Cotner ${ }^{2}$ \\ Department of Ecology, Evolution and Behavior, University of Minnesota, St. Paul, Minnesota 55108 USA \\ José V. Montoya ${ }^{3}$ \\ Section of Ecology, Evolutionary Biology and Systematics, Department of Wildlife and Fisheries Sciences, \\ Texas AEM University, 2258 TAMU, College Station, Texas 77843-2258 USA

\section{Carlos E. Del Castillo ${ }^{4}$} \\ Earth Science Applications Directorate, US National Aeronautics and Space Administration, Building 1100, \\ Stennis Space Center, Mississippi 39529 USA

\section{Stephen E. Davis ${ }^{5}$, Jennifer A. Snider ${ }^{6}$, George M. Gable ${ }^{7}$, AND Kirk O. Winemiller \\ Section of Ecology, Evolutionary Biology and Systematics, Department of Wildlife and Fisheries Sciences, Texas AEM University, 2258 TAMU, College Station, Texas 77843-2258 USA}

\begin{abstract}
The Cinaruco River, an oligotrophic ecosystem in the Venezuelan llanos (savanna), has strong seasonal hydrology and supports large populations of ecologically diverse fishes. The relative contributions of autochthonous and allochthonous production sources that support high stocks of secondary consumers are undetermined in this river. We used excitation-emission fluorescence spectroscopy and absorption spectra of dissolved organic matter to infer degradation of leaf material originating from the surrounding gallery forest. During the low-water period, a large fraction of fluorescent organic matter contained in leaves degraded quickly in river water and was an important allochthonous contribution of $C$ to the system. However, the fluorescence signature of dissolved organic matter in lagoons was different from that of the main river channel during the falling-water period, suggesting that other sources of $\mathrm{C}$ were present. Allochthonous organic matter clearly fueled microbial respiration during the falling-water period, but our in-water experiments using light-dark bottle methods indicated that autochthonous production was an important supplementary $\mathrm{C}$ source in shallow nearshore waters. During the low-water and falling-water periods, water-column primary production in nearshore waters ranged from 150 to $500 \mathrm{mg} \mathrm{C} \mathrm{m}^{-2} \mathrm{~d}^{-1}$ and was $2 \times$ greater than community respiration, i.e., the nearshore component of the water column was net autotrophic. Benthic primary production in nearshore areas where light reached the sediments ranged between 350 and $500 \mathrm{mg} \mathrm{C}$ $\mathrm{m}^{-2} \mathrm{~d}^{-1}$ and was about equal to community respiration. Primary production was probably limited by the availability of dissolved inorganic $\mathrm{N}$, which sometimes was below detection limits of $\sim 0.5 \mu \mathrm{M}$ (mean $\sim 0.25$ $\mu \mathrm{M})$. Our results support the idea that autotrophic production is an important $\mathrm{C}$ source in neotropical rivers.
\end{abstract}

Key words: excitation-emission matrices, absorption spectra, allochthonous, autochthonous, carbon, neotropical, Cinaruco River, lagoon.

${ }^{1}$ E-mail addresses: droelke@tamu.edu

2 cotne002@umn.edu

3 jvmontoya@tamu.edu

4 carlos.e.delcastillo@nasa.gov

5 sedavis@tamu.edu

6 jensnider1230@hotmail.com

7 gotgame26@hotmail.com

8 k-winemiller@tamu.edu
Neotropical floodplain rivers typically are associated with a prolonged annual flood pulse during which much of the landscape becomes inundated (Junk et al. 1989). Energy stored on the terrestrial landscape is transferred to the river environment through multiple processes during periods of inunda- 
tion. For example, organisms such as fish and invertebrates graze directly on detritus and algae (Goulding 1980, Araujo-Lima et al. 1986, Forsberg et al. 1993), bacterial production is stimulated by leaching of organic $\mathrm{C}$, and release of inorganic nutrients stimulates autotrophic production (Bayley and Petrere 1989, Junk et al. 1989, Castillo et al. 2003).

The flow of energy into the river from neighboring grasslands and forest is greatly reduced during lowwater periods, and the biomass of higher trophic levels increases as populations are concentrated in the receding waters of the river. What sustains this biomass during low-water periods? Studies in the Cinaruco River have suggested that higher tropic levels may be sustained by predation on migratory fish populations that act as foodweb subsidies (Winemiller and Jepsen 1998, 2004). Another possibility is that high biomass at higher trophic levels may be sustainable only because organisms change their behavior and level of activity to conserve energy during periods of low food availability or energy density (Arrington et al. 2002). Studies in the Amazon River system showed that allochthonous inputs may remain important sources of $C$ as submerged litter continues to degrade and photochemical reactions with refractory dissolved organic matter produce derivative compounds that are more labile than the original compounds (Amon and Benner 1996b). Studies in the Amazon and Orinoco Rivers and many temperate rivers indicate that autochthonous production might also be an important source of $\mathrm{C}$ during low-water periods (Hamilton et al. 1992, Amon and Benner 1996b, Waichman 1996, Thorp and Delong 2002).

The Cinaruco River is an oligotrophic, low-pH tributary to the Orinoco River in the Venezuelan llanos. During low-water periods, the river supports large populations of ecologically diverse fishes (Winemiller and Jepsen 2004). This higher-trophic-level biomass may be supported, in part, by biofilms (sensu Wetzel 2001). Preliminary experimental data from fish exclosure experiments in this system (Winemiller et al. 2006) showed that biofilms built up rapidly on sediments in the absence of fish, and little of this material consisted of chlorophyll $a$. In other words, the biofilms were strongly heterotrophic with autotrophic indices (ash-free dry mass/chlorophyll a) >5000 (DR, unpublished data). In the presence of fish, biofilms did not accumulate because of heavy grazing (Winemiller et al. 2006).

Our objectives were 3-fold. First, we focused on the role of a gallery forest fringing our study area to better understand the sources of organic $C$ that might be fueling the rapid formation of biofilms. Second, we quantified the degree of heterotrophy in this area of the Cinaruco River. Third, we tried to elucidate possible flood-pulse-linked differences in sources of $\mathrm{C}$ and degree of heterotrophy by sampling during lowwater and falling-water periods.

\section{Methods}

\section{Study area}

The section of the Cinaruco River on which we focused is surrounded by igapó (gallery forest that is periodically inundated with blackwater). The leguminous tree Campsiandra sp. is prevalent; other tree species common to this gallery forest habitat include various palms (e.g., Copernicia tectorum), saman and masaguaros (e.g., Pithecellobium saman and P. guachapele), figs (Ficus spp.), caruta (e.g., Genipa americana), palo de agua (e.g., Cordia collococa), and camoruco (e.g., Sterculia apetala) (Ramia 1967, Troth 1979). Much of the basin consists of open grassland (dominated by Poaceae, i.e., Trachypogon sp. and Mesosetum sp.) that is inundated during periods of high water. Our recent research has involved sampling throughout the year at many locations along the river and within lagoons (Montoya et al. 2006), but here we focus only on sampling stations along the river (mostly sand substrate) and within Laguna Larga (substrates ranging from sand to sand-clay). The lagoon is $\sim 3.3 \mathrm{~km}$ long and remains connected to the main river channel throughout the year (Fig. 1).

We collected samples during 2 different periods of the hydrological cycle in 2002: the low-water period (March) when water temperatures were $\sim 31.6^{\circ} \mathrm{C}$, and the falling-water period (November-December) when water temperatures were $\sim 29.3^{\circ} \mathrm{C}$. During the lowwater period, little water was exchanged between the lagoon and river, and net flow was from the lagoon to the river. During the falling-water period, sheet flow occurred across much of the inundated landscape. Because the boundaries of the river and lagoon were difficult to discern at this time, the extent of water exchanged between the lagoon and river was difficult to estimate.

We measured optical properties of the water (see below) at one river and one lagoon station during the low-water and falling-water periods. We measured water-column and benthic primary production and community respiration (see below) and a suite of water-quality variables (see below) at 5 to 7 lagoon and river stations, including the 2 stations used for optical analyses during the low-water and fallingwater periods. These stations were selected based on accessibility of the nearshore environment because the changing shoreline with the flood pulse made it 


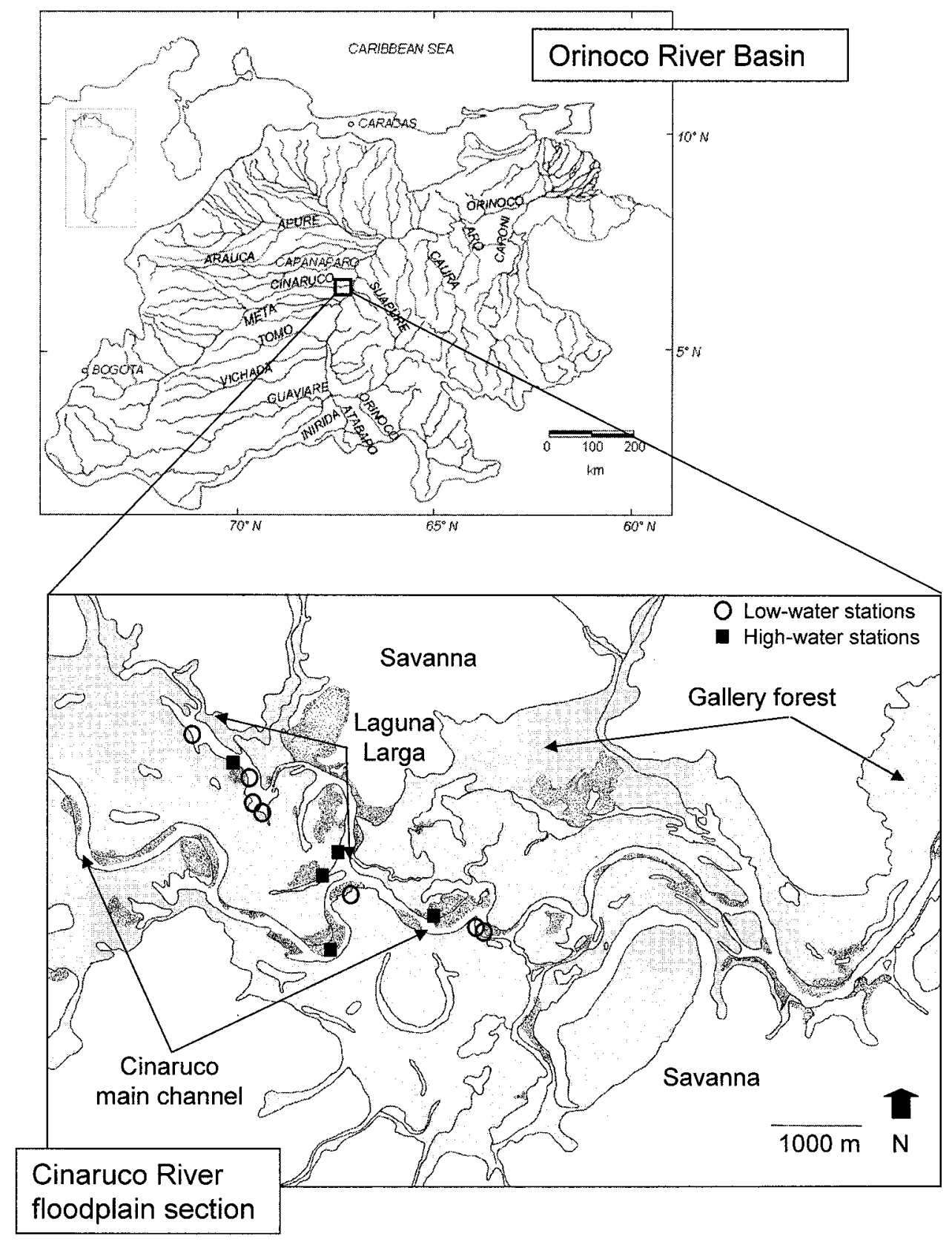

FIG. 1. The Cinaruco River in the Orinoco River Basin (A) and the location of sampling sites (low water: circles; falling water: squares) (B). Savanna (white) and gallery forest (gray) also are shown.

impossible to visit the same stations during the lowwater and falling-water periods.

\section{Optical analysis of dissolved organic matter (DOM)}

DOM signatures.-Our optical analyses characterized the signature of a DOM source, not the absolute concentration of specific chemicals. We estimated sources and transformations of DOM by measuring fluorescence and absorption spectra (Coble et al. 1990,
1993, Coble 1996) of DOM from the water at Laguna Larga and the river. We also measured fluorescence and absorption spectra of DOM extracted from leaves from several locations throughout the gallery forest so we could trace the signature of DOM originating from the gallery forest (leaves falling directly into the water and submerged leaves clustered in snags) in waters of the lagoon and river. The contribution of DOM originating from the gallery forest to total DOM was most likely maximized during the low-water period 
because runoff was not observed and water exchanges between the lagoon and river were small. The contribution of gallery forest DOM to total DOM was most likely minimized during the falling-water period because the period of maximum inundation of the landscape had just ended, and dilution of DOM originating from the gallery forest was greatest.

Water samples.-We collected water samples from one station in Laguna Larga and from a river station just upstream of the lagoon during the low-water and falling-water periods. We filtered water samples (Whatman GF/F, $0.7 \mu \mathrm{m}$ ) to remove large particles, and we stored all water samples frozen in opaque vials until analysis (Davis et al. 2003).

Leaf samples.-We analyzed DOM signatures for 3 categories of leaves: attached (alive and fresh), fallen (<1-y-old senesced leaves not yet submerged), and submerged ( 1-3-y-old senesced leaves collected below the waterline). We were able to distinguish fallen and submerged leaves on the basis of leaf color and integrity. We collected leaves in each category from many tree species, and we ensured that leaf types were evenly represented based on mass. We collected attached and fallen leaves from many locations throughout the gallery forest and submerged leaves from many locations throughout the lagoon, and pooled them into composite samples. We did not collect submerged leaves from the river channel because high flow rates swept them away. Leaf samples were transported to the USA (Texas A\&M University) within $3 \mathrm{~d}$ of collection.

We dried leaves from each sample to a constant mass at $70^{\circ} \mathrm{C}$ and partitioned samples into 3 subsamples, each $\sim 15 \mathrm{~g}$ dry mass (DM). We leached each subsample in $1 \mathrm{~L}$ of ultrapure $(18 \mathrm{Mohm})$ deionized water for $48 \mathrm{~h}$ and then filtered the leachate to remove any large particles (Whatman GF/F, $0.7 \mu \mathrm{m}$ ). This extraction procedure resulted in mean total organic $\mathrm{C}$ leaching rates of $1.9,0.7$, and $0.05 \mathrm{mmol} \mathrm{C} \mathrm{g}^{-1} \mathrm{DM} \mathrm{d}^{-1}$, for attached, fallen, and submerged leaves, respectively.

Optical analysis.-We determined fluorescence spectra, or 3-dimensional excitation-emission matrices (EEMs), for each DOM sample using a SPEX Fluorolog II fluorescence spectrophotometer running in ratio mode with a bandpass of $5 \mathrm{~nm}$. We created EEMs by measuring the emission spectra from 250 to $700 \mathrm{~nm}$ at 40 separate excitation wavelengths ranging between 230 and $465 \mathrm{~nm}$ and concatenating the emissions scans to form the EEMs. We processed data and corrected for optical biases of the instrument according to Coble et al. (1993). We transformed the fluorescence intensities at each emission maximum to equivalents of quinine sulfate dihydrate expressed in parts per billion (ppb QSE).

A characteristic of EEMs is that labile chemicals contribute more significantly to peaks found at shorter emission wavelengths; these compounds are typically of lower molecular weight and more readily used by microbes. Refractory chemicals contribute more significantly to peaks found at longer emission wavelengths. When peaks of an EEM shift to the right (i.e., from shorter to longer wavelengths) through time, a phenomena called red-shift, the chemical matrix has been transformed and is more refractory (see Klapper et al. 2002). We used the EEM data to characterize the signature of the DOM originating from the gallery forest, based on the measured excitation-emission pairs. To compare chemical characteristics of samples, we inspected the EEMs visually, where peak heights were used to determine relative abundances of chemical types, and red-shifted peaks were used to infer that chemical types had become more refractory over time.

We recorded absorption spectra of all composite leaf extracts and lagoon and river DOM at wavelengths between 200 and $400 \mathrm{~nm}$ using a Hitachi U-3300 dualbeam spectrophotometer equipped with $1-\mathrm{cm}$ quartz cells. We used ultrapure (18 Mohm) deionized water as a reference. We diluted samples that had high absorbance values before making fluorescence measurements to avoid self-shading effects, and we used the dilution factors to calculate final fluorescence intensities. We report values as absorbance. To further compare chemical characteristics of samples, we inspected the absorption curves visually, and we calculated spectral slopes between 290 and $400 \mathrm{~nm}$. We used the spectral slopes from all composite leaf extracts and DOM samples when assessing differences in slope between low-water and falling-water periods, and we determined significance using a Student's $t$ test $(n=5)$.

\section{Primary production and community respiration}

Water column.-We used a traditional light-dark bottle technique to measure water-column primary production and community respiration (Wetzel and Likens 1991). We deployed one set of bottles (2 transparent and 1 opaque) in situ $0.3 \mathrm{~m}$ below the water surface, and another set at the sediment-water interface (adjacent to the benthic chambers, discussed below). We incubated bottles for 2 to $4 \mathrm{~h}$; the incubation time always spanned the noon hour. We measured changes in dissolved $\mathrm{O}_{2}$ using a YSI Model 95 dissolved $\mathrm{O}_{2}$ probe. We determined primary production and community respiration $\left(\mathrm{mg} \mathrm{C} \mathrm{m} \mathrm{m}^{-3}\right.$ 
$\mathrm{h}^{-1}$ ) using equations in (Wetzel and Likens 1991) with photosynthetic $\left(\mathrm{CO}_{2} / \mathrm{O}_{2}\right)$ and respiratory $\left(\mathrm{O}_{2} / \mathrm{CO}_{2}\right)$ quotients both equal to 1 . We converted estimates of water-column production and community respiration to aeral estimates (mg C m${ }^{-2} \mathrm{~h}^{-1}$ ) by averaging volumetric values obtained from the surface and bottom and multiplying by the water-column depth (consistent between sites at $0.7 \mathrm{~m}$ ). We calculated daily estimates by multiplying hourly values by 12 or $24 \mathrm{~h}$ for photosynthesis and respiration, respectively. We used Student's $t$-tests to compare water-column primary production and respiration in the lagoon ( $n$ $=6)$ and river $(n=5)$ during low-water and fallingwater periods. Benthos.-We used a modified lightdark bottle technique to estimate benthic production and community respiration. Light and dark chambers were placed at the sediment-water interface, thereby enclosing a known volume of water and surface area of benthos, for 2 to $4 \mathrm{~h}$ (Fejes et al. 2005). Dissolved $\mathrm{O}_{2}$ concentrations were determined at 5-min intervals using Hydrolab datalogging multiprobes. We used $\mathrm{O}_{2}$ measurements obtained from bottles deployed at the sediment-water interface to correct chamber measurement for changes in the dissolved $\mathrm{O}_{2}$ concentration that originated from the water trapped in the headspace of the benthic chambers. We used equations in Wetzel and Likens (1991) to estimate rates of primary production and community respiration. We obtained areal estimates $\left(\mathrm{mg} \mathrm{C} \mathrm{m}^{-2} \mathrm{~d}^{-1}\right)$ of daily production and respiration by multiplying the corrected chamber values by the height of the chamber $(0.125 \mathrm{~m})$ and by 12 or $24 \mathrm{~h}$ for photosynthesis and respiration, respectively. We used Student's $t$-tests to compare benthic primary production and respiration in the lagoon $(n=20)$ and river $(n=22)$ during low-water and falling-water periods.

Photochemical consumption of dissolved $\mathrm{O}_{2}$ occurs to a limited extent in the Amazon River system (Amon and Benner 1996b) and might also occur in the Orinoco Basin. We tested for photochemical reactions during the period of our incubations by conducting incubations using GF/F-filtered water (assuming that the filter removed most biotic components from the water). During these incubations, we measured no change in dissolved $\mathrm{O}_{2}$ concentrations, indicating that photochemical reactions were not a significant factor during our incubations.

\section{Chlorophyll a, light, and dissolved inorganic nutrients}

We measured chlorophyll a concentrations in 3 water-column and 3 benthic samples at each sampling station. We filtered water samples $(100 \mathrm{~mL})$ from the water column through a GF/F filter and froze the filters until analysis. We collected benthic samples by pressing an inverted, open Petri dish $1.3 \mathrm{~cm}$ into the upper layers of the sediment, gently recapping the Petri dish, and then removing the dish with its contents. We extracted chlorophyll $a$ from Petri-dish sediment cores and filters from the water column with 90\% acetone, and we analyzed these samples using spectrofluorometric methods (APHA 1998).

We measured Secchi depths at each sampling station. When the river or lagoon bottom was visible from the surface, we made this measurement at deeper locations adjacent to each shoreline station where we could not see the bottom.

We collected 2 water samples for quantification of dissolved inorganic nutrients at each sampling station by passing water through a GF/F filter and freezing the filtrate for transportation to the laboratory. We measured $\mathrm{NO}_{3}, \mathrm{NO}_{2}, \mathrm{NH}_{4}$, urea, soluble reactive $\mathrm{P}$ (SRP), and silica $\left(\mathrm{SiO}_{3}\right)$ using autoanalyzer technology (Grasshoff et al. 1983). Detection limits for these nutrients were $0.089 \mu \mathrm{M}\left(\mathrm{NO}_{3}\right), 0.009 \mu \mathrm{M}\left(\mathrm{NO}_{2}\right)$, $0.035 \mu \mathrm{M}\left(\mathrm{NH}_{4}\right), 0.161 \mu \mathrm{M}$ (urea), $0.024 \mu \mathrm{M}$ (SRP), and $0.071 \mu \mathrm{M}\left(\mathrm{SiO}_{3}\right)$. We calculated dissolved inorganic nitrogen (DIN) by summing $\mathrm{NO}_{3}, \mathrm{NO}_{2}, \mathrm{NH}_{4}$, and urea. We compared chlorophyll $a$, light, and inorganic nutrients between the lagoon and river during lowwater and falling-water periods by visual inspection of the data.

\section{Results}

\section{Optical analyses}

EEMs from attached and fallen leaves differed during low-water and falling-water periods. During the low-water period, the EEM from attached leaves had 3 pronounced peaks at excitation-emission pairs 285-345 nm, 260-440 nm, and 308-438 nm, whereas the EEM from fallen leaves did not have a $285-345 \mathrm{~nm}$ peak (Fig. 2A, C). During the falling-water period, the EEM from attached leaves had one pronounced peak at excitation-emission pair $270-300 \mathrm{~nm}$ and 3 lessdistinctive peaks at excitation-emission pairs 255-450 $\mathrm{nm}, 300-445 \mathrm{~nm}$, and $420-465 \mathrm{~nm}$, whereas the EEM from fallen leaves had only one distinct peak at 270$300 \mathrm{~nm}$ (Fig. 2B, D).

EEMs from leaves that were submerged in the lagoon were very similar to EEMs from lagoon DOM during low-water and falling-water periods. During the low-water period, peaks were observed at excitation-emission pairs $265-440 \mathrm{~nm}$ and $335-445 \mathrm{~nm}$ for submerged leaves and lagoon DOM, but peak flattening (indicating lower concentrations of chemicals associated with each peak) was apparent in the EEM for lagoon DOM (Fig. 3A, C). During the falling- 


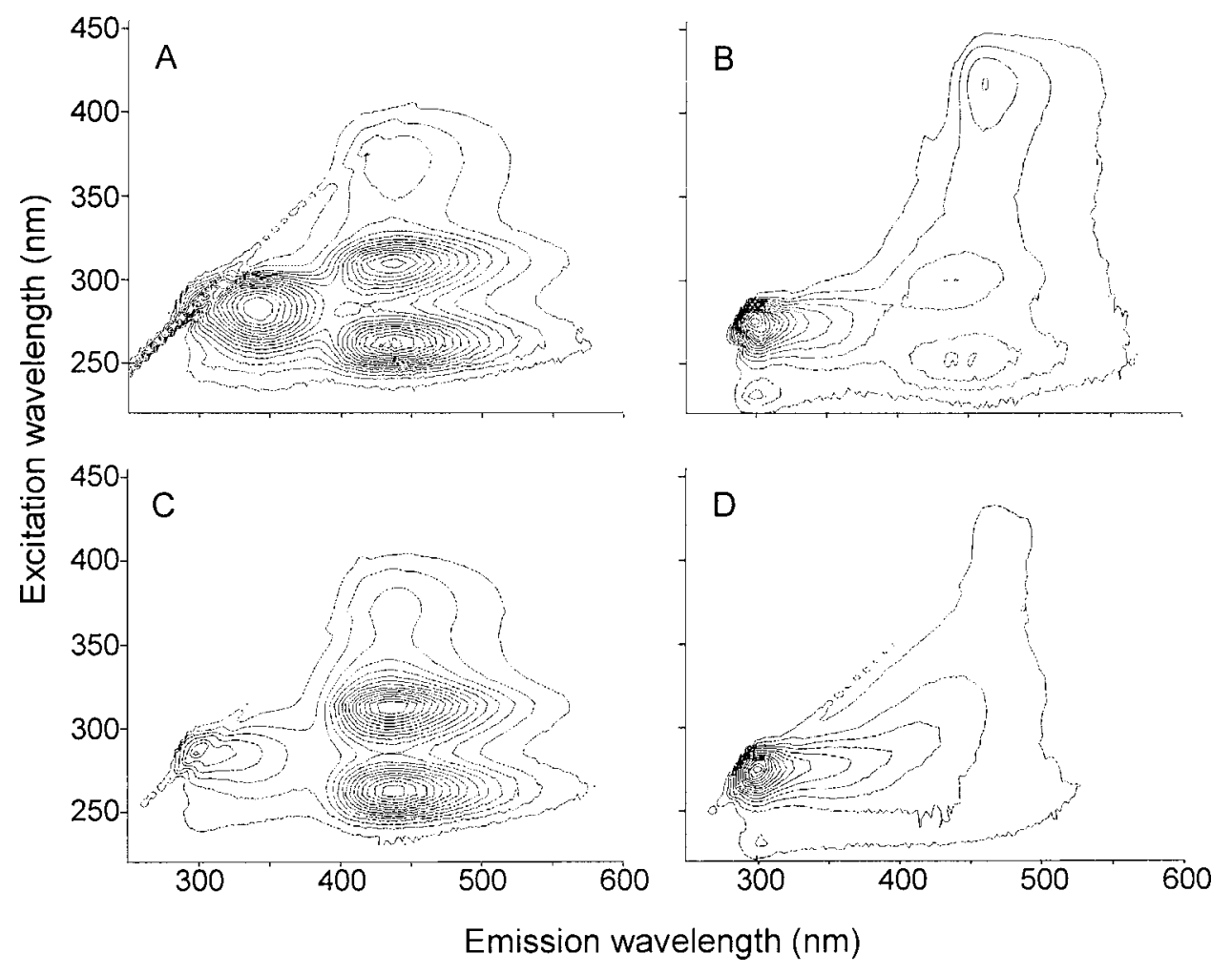

FIG. 2. Excitation-emission matrices (EEMs) for composite leaf extracts from attached leaves during the low-water (A) and falling-water (B) periods and for fallen leaves during the low-water (C) and falling-water (D) periods.

water period, peaks were observed at excitationemission pairs 235-345 $\mathrm{nm}$ and 275-335 $\mathrm{nm}$ for submerged leaves and lagoon DOM (Fig. 3B, D). EEMs for fallen and submerged leaves were similar during the low-water period, with much peak flattening apparent in the submerged-leaf EEM (Figs 2C, $3 \mathrm{~A})$, but EEMs for fallen and submerged leaves were dissimilar during the falling-water period (Figs 2D, 3B). Visual comparisons between attached-, fallen-, and submerged-leaf extracts and lagoon DOM during low-water and falling-water periods indicated no redshift of peaks.

Similarity between lagoon and river DOM was dependent on time of year. For example, EEMs of lagoon and river DOM were nearly identical during the low-water period (Fig. 3C, E). However, during the falling-water period, EEMs of lagoon and river DOM were dissimilar, with an additional peak found at excitation-emission pair $295-405 \mathrm{~nm}$ in the river DOM (Fig. 3D, F).

Absorption measurements showed trends similar to those from EEMs. For example, absorption spectra from attached leaves were different from absorption spectra from fallen leaves during low-water and falling-water periods. Absorption curves from at- tached leaves were more structured, e.g., the small peaks at $280 \mathrm{~nm}$ were more defined (Fig. 4A, B), than curves from fallen leaves. During the low-water period, absorption spectra of submerged leaves and lagoon DOM were similar (Fig. 4A). However, during the falling-water period, the absorption peak at $225 \mathrm{~nm}$ was much more defined in the submerged leaves than in the lagoon DOM (Fig. 4B). Lagoon and river DOM were nearly identical during the low-water period (Fig. 5). During the falling-water period, lagoon and river DOM differed; the absorption spectra of the lagoon DOM had a well-developed shoulder at $230 \mathrm{~nm}$ that the river DOM lacked. Last, the spectral slope between 290 and $400 \mathrm{~nm}$ for all composite leaf extracts and DOM samples was greater during the low-water period than during the falling-water period (Student's $t$-test, $\mathrm{p}<0.05)$.

\section{Primary production and community respiration}

Primary production was significantly greater than respiration in the nearshore water columns in the river and lagoon during low-water and falling-water periods (Student's $t$-tests, $p<0.05$ ). Thus, the nearshore water columns were net autotrophic. Water-column primary production was typically $\sim 2 \times$ greater than 

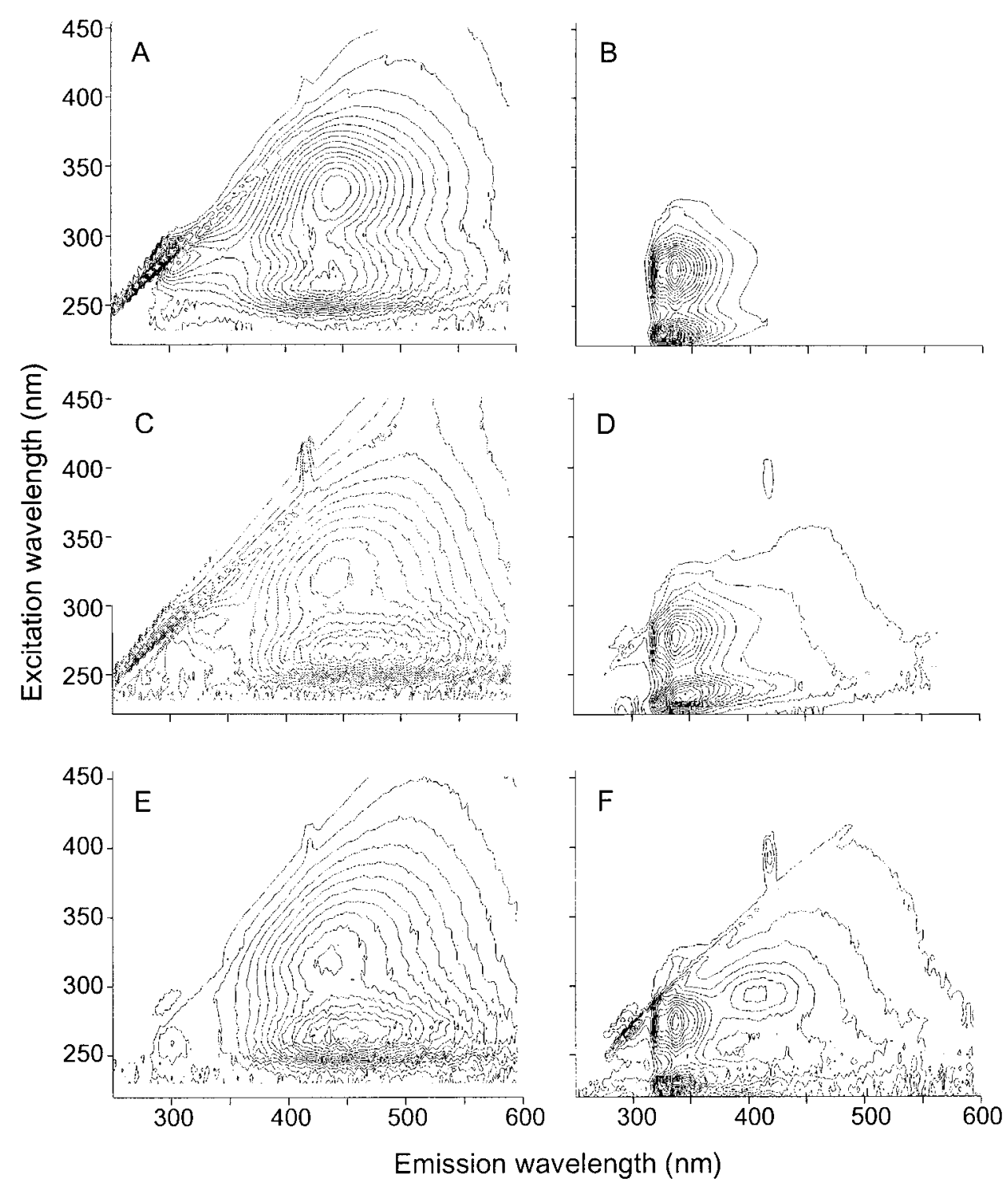

FIG. 3. Excitation-emission matrices (EEMs) for leaf composite extracts from submerged leaves during the low-water (A) and falling-water periods (B), from lagoon dissolved organic matter (DOM) during the low-water (C) and falling-water periods (D), and from river DOM during the low-water $(\mathrm{E})$ and falling-water $(\mathrm{F})$ periods.

water-column community respiration in both the lagoon and river (Fig. 6A, B). The highest values for water-column primary production and respiration ( $\sim 500$ and $\sim 220 \mathrm{mg} \mathrm{C} \mathrm{m}^{-2} \mathrm{~d}^{-1}$, respectively) occurred in the lagoon during the low-water period (Fig. 6A).

Primary production and community respiration in the benthos did not differ during the low-water period in either the lagoon or river (Student's $t$-tests, $p>$ 0.05). However, primary production was significantly greater than respiration in the benthos during the falling-water period (Student's $t$-tests, $p<0.05$ ) when benthic primary production was $\sim 25 \%$ greater than benthic respiration in both the lagoon and river (Fig. $6 \mathrm{C}, \mathrm{D})$. During the low-water period, benthic primary production and respiration tended to be higher (mean value for both $\sim 500 \mathrm{mg} \mathrm{C} \mathrm{m}^{-2} \mathrm{~d}^{-1}$ ) in the lagoon than in the river, whereas during the falling water period, benthic production and respiration were similar in both locations (Fig. 6C, D).

Water-column and benthic chlorophyll $a$ were greater in the lagoon than in the river during the low-water period (Fig. 7A, C) when chlorophyll $a$ concentrations were $\sim 3.9$ and $\sim 5.2 \mathrm{mg} / \mathrm{m}^{2}$ for the water column and benthos, respectively. Chlorophyll a concentrations were similar in the lagoon and river water column during falling-water (Fig. 7B). The lowest chlorophyll $a$ concentrations occurred in the benthos during the 


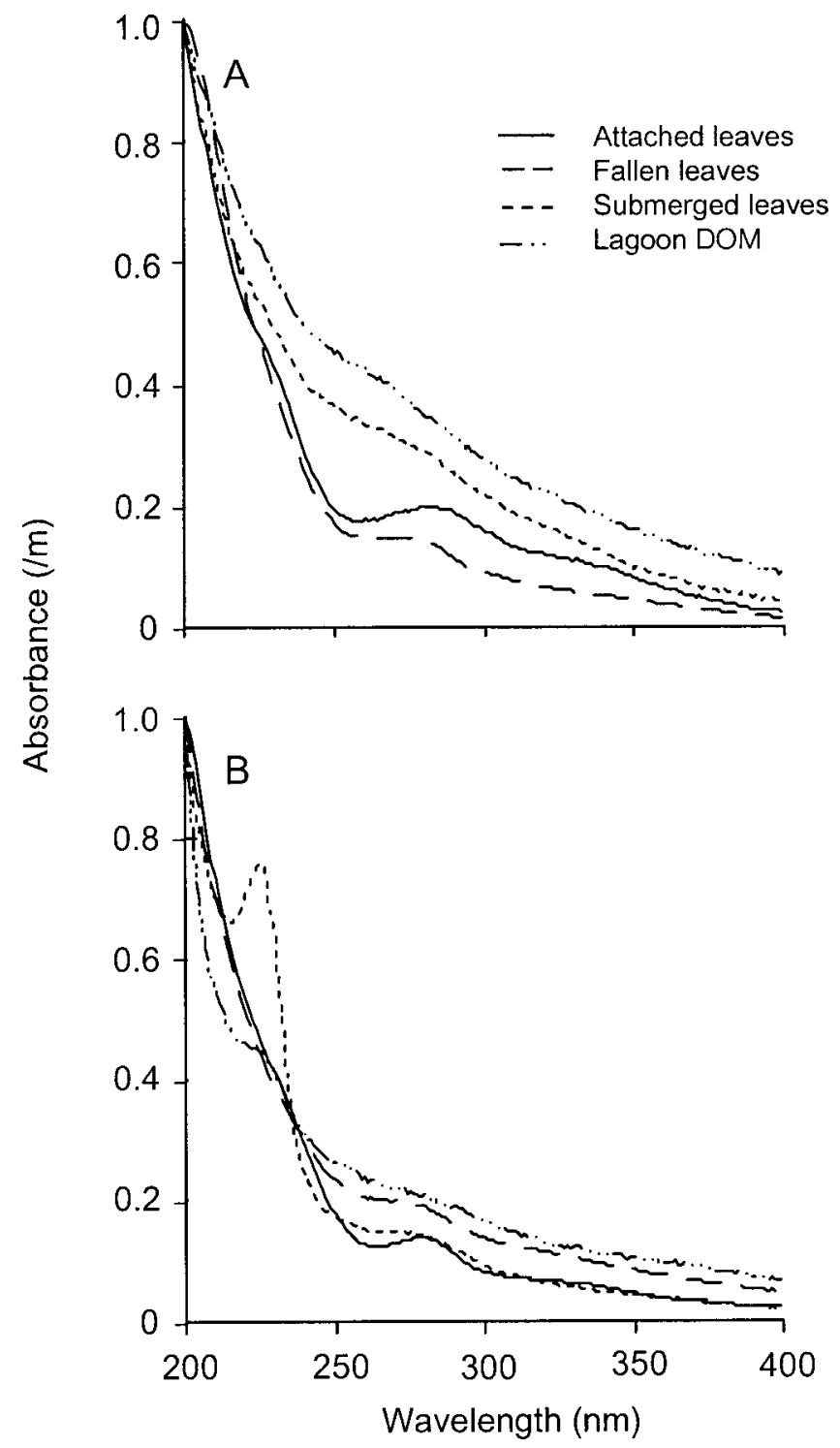

FIG. 4. Absorption spectra for composite leaf extracts and lagoon dissolved organic matter (DOM) during low-water (A) and falling-water (B) periods.

falling-water period $\left(\sim 0.05 \mathrm{mg} / \mathrm{m}^{2}\right.$ and negligible in the lagoon and river, respectively; Fig. 7D).

\section{Light and dissolved inorganic nutrients}

Light penetration was fairly consistent during the low-water and falling-water periods in both the lagoon and river. Secchi disk depths ranged between $\sim 0.8$ and $\sim 1.2 \mathrm{~m}$ (Fig. 8A, B). DIN was highly variable and ranged from $<0.1 \mu \mathrm{M}$ to $\sim 0.5 \mu \mathrm{M}$ (Fig. $8 \mathrm{C}$, D). SRP was less variable than DIN and ranged from $\sim 0.05$ to $\sim 0.16 \mu \mathrm{M}$ (Fig. 8E, F). The DIN:SRP ratio was never $>10(\mu \mathrm{M}: \mu \mathrm{M})$, indicating that if one of these nutrients were to become limiting, it probably would be DIN.

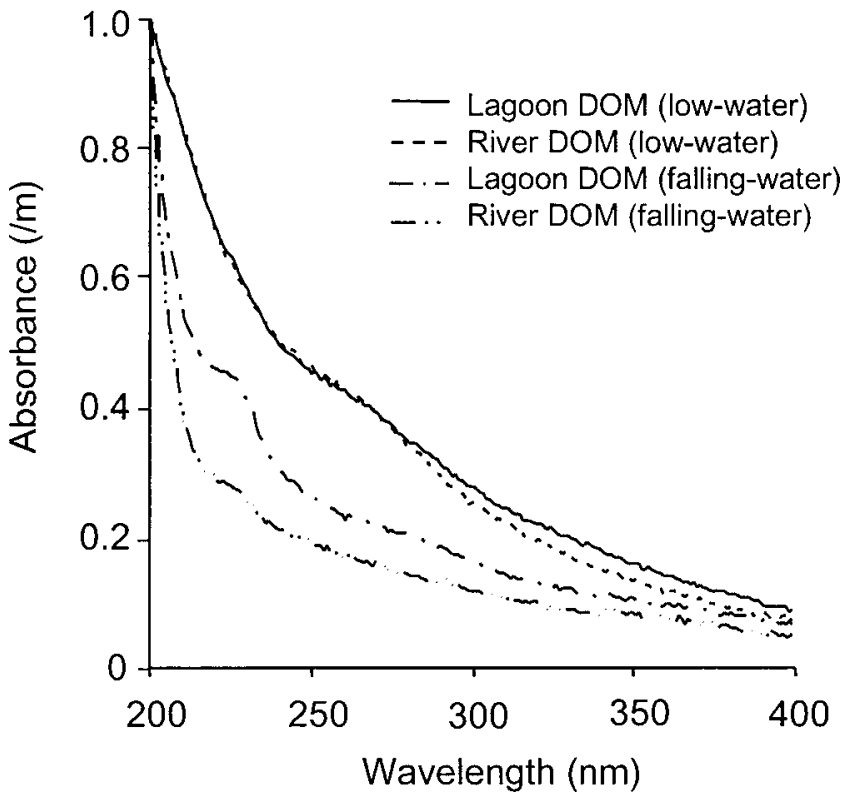

FIG. 5. Absorption spectra for lagoon and river dissolved organic matter (DOM) during low-water and falling-water periods.

$\mathrm{SiO}_{3}$ was very dynamic and ranged from a minimum of $<10 \mu \mathrm{M}$ in the lagoon during the falling-water period to a maximum $>200 \mu \mathrm{M}$ in the river during the low-water period (Fig. 8G, H).

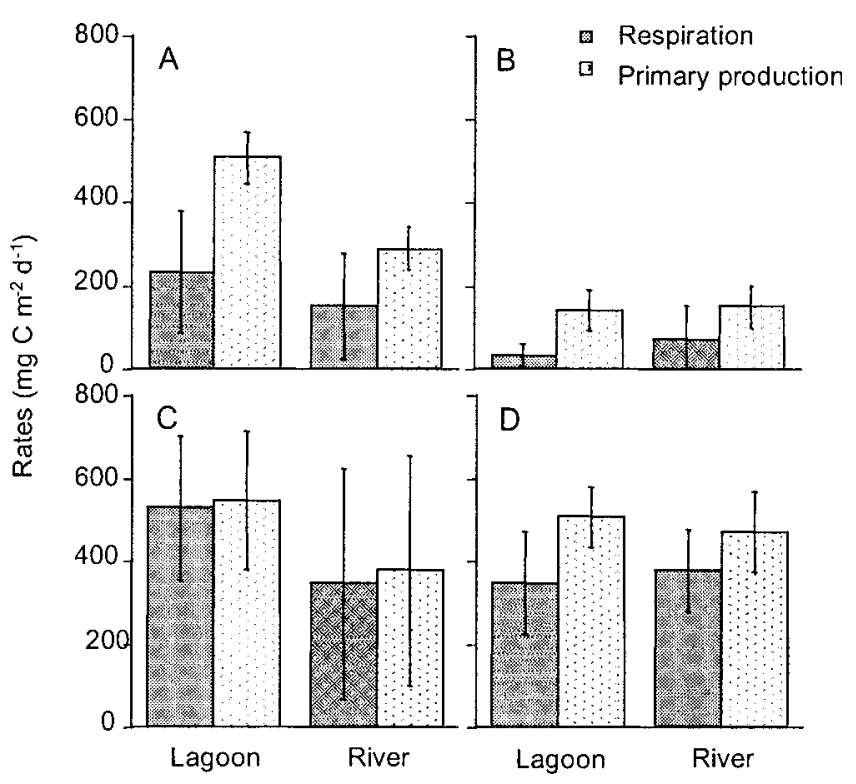

FIG. 6. Mean ( \pm 1 SD) nearshore water-column and benthic primary production and community respiration during low-water and falling-water periods. A.-Water column, low-water period. B.-Water column, falling-water period. C.-Benthic, low-water period. D.-Benthic, fallingwater period. 


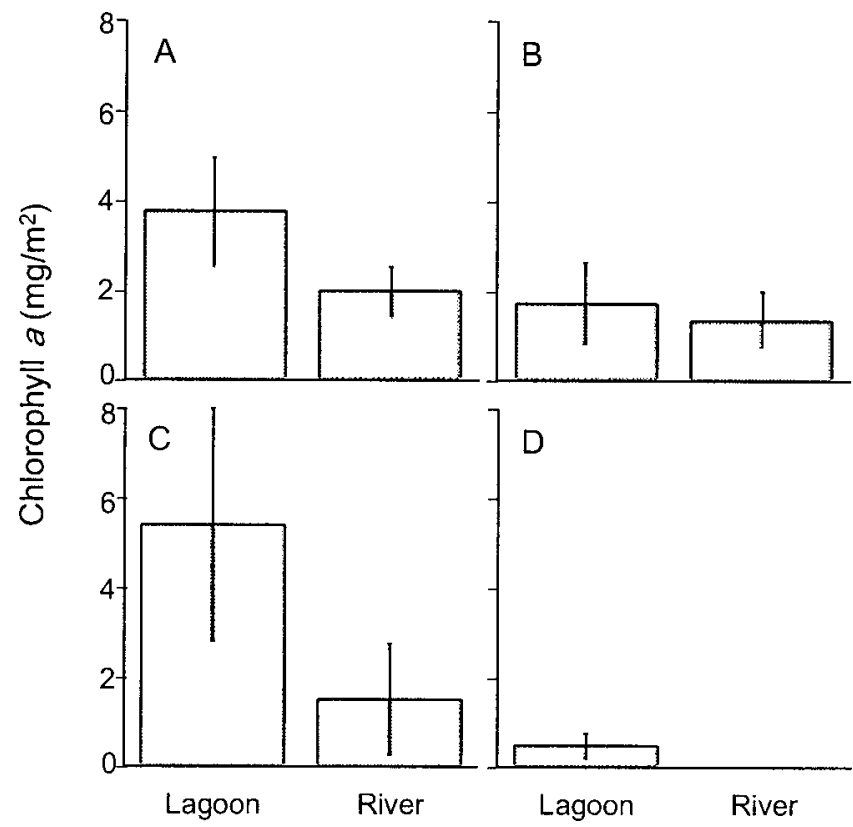

FIG. 7. Mean ( \pm 1 SD) nearshore water-column and benthic chlorophyll a concentrations during low-water and falling-water periods. A.-Water column, low-water period. B.-Water column, falling-water period. C.-Benthic, lowwater period. D.-Benthic, falling-water period.

\section{Discussion}

\section{DOM signatures as tracers of organic matter}

Chemical constituents released by soils that are inundated during high-water periods are thought to dominate allochthonous $\mathrm{C}$ sources to floodplain systems. This idea is supported by observations in the Amazon River Basin where the bulk of DOM consists of highly degraded aromatic compounds originating from soil humic and fulvic acids (Ertel et al. 1986, Hedges et al. 1994). Our optical characterization of DOM did not differentiate between types of aromatic compounds, nor did it quantify the proportions of aromatic and aliphatic compounds. However, it did reveal a strong similarity between fallen leaves, submerged leaves, and surface water DOM. This evidence indicates that leaves dropped from the gallery forest were a significant and direct source of DOM to the lagoon and river.

Our EEM data showed no red-shift, which would have indicated a relative decrease in more-labile compounds (Klapper et al. 2002). Instead, we observed peak flattening, which indicates that the types of organic compounds found in leaves also were found in the water, but in lower concentrations. The absence of a red-shift also suggests that allochthonous material entering the river from soils, which should have been highly reduced, was not a prominent source of $C$ to the
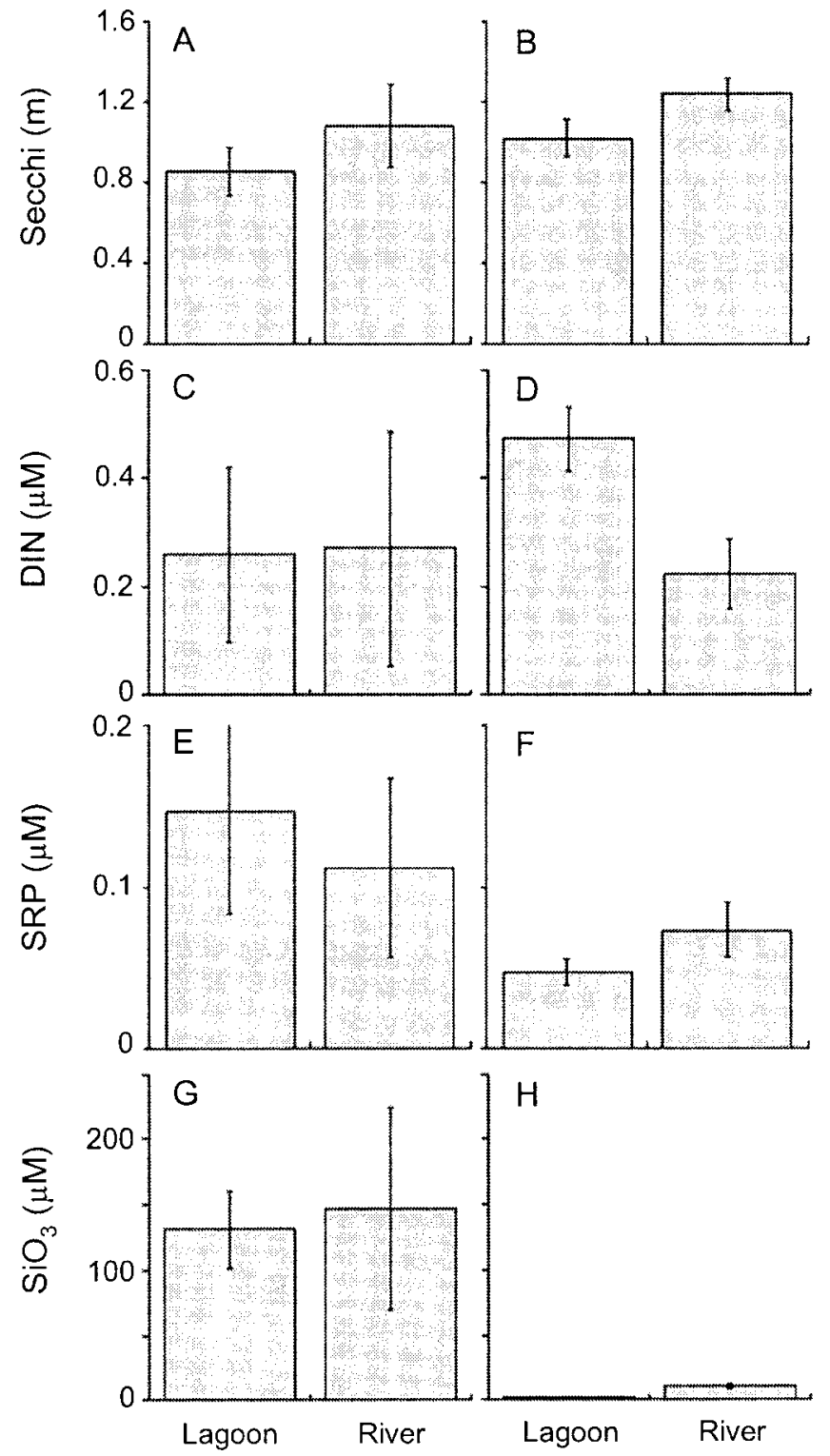

Fig. 8. Mean ( $\pm 1 \mathrm{SD})$ nearshore lagoon and river levels of light and nutrients during low-water and falling-water periods. A.-Secchi disk depth, low-water period. B.Secchi disk depth, falling-water period. C.-Dissolved inorganic N (DIN), low-water period. D.-DIN, falling-water period. E.-Soluble reactive $\mathrm{P}$ (SRP), low-water period. F.SRP, falling-water period. G.-Silica $\left(\mathrm{SiO}_{3}\right)$, low-water period. H.- $-\mathrm{SiO}_{3}$, falling-water period.

river. It may be that the sandy soils in this area of the Cinaruco retain little organic material and, therefore, the gallery forest is the predominant source of (relatively fresh) allochthonous material to the river. The differences between the EEMs from fallen- and submerged-leaf extracts probably represent the morelabile compounds that quickly leach from newly submerged material and are readily used by microbes. 
Cammack et al. (2004) showed that fluorescent peaks at shorter emission wavelengths correlated very well with bacterial activity.

\section{Seasonal changes in spectral signatures}

The importance of this allochthonous pathway (leaves from the gallery forest) may change seasonally. For example, DOM signatures of leaf extracts and lagoon and river DOM were more similar during the low-water period than the falling-water period. During the falling-water period, river DOM differed from the leaf extracts and lagoon DOM. This difference suggests that another source of DOM may have been important in the system. One possible source of DOM that was not evaluated in our study is upstream, inundated grasslands adjacent to the river. Grasslands were a source of DOM in the Surumoni River, another oligotrophic tributary to the Orinoco River (Battin 1998). Our results also are consistent with previous research showing that the processes defining the signature of river DOM in the Amazon occurred along the river corridor (McClain et al. 1997).

Many plants in tropical forests relocate nutrients from senescent leaves to younger leaves before abscission as a means of efficient resource allocation (Vitousek 1982, 1984, Jordan 1985, Barrios and Herrera 1994). The differences in the EEMs and absorption spectra of DOM extracted from attached and fallen leaves suggest that trees in the gallery forest in our system may relocate compounds from leaves approaching senescence. However, the EEMs from attached leaves during the low-water period differed from attached-leaf EEMs during the falling-water period. This difference may have been a consequence of seasonal changes in environmental variables that stress floodplain vegetation and affect the chemical composition of leaves.

Another seasonal difference in the DOM was observed in the spectral slope between 290 and 400 $\mathrm{nm}$. Greater slopes in this region of the absorption curve indicate the prevalence of low-molecular-weight compounds (Carder et al. 1989, Obernosterer and Benner 2004). Spectral slopes in all composite leaf extracts and DOM samples from the lagoon and river water columns were consistently greater during the low-water period than the falling-water period. This result suggests that low-molecular-weight compounds may have been more prevalent during the low-water period, a conclusion consistent with the EEM data, which indicated seasonal differences in DOM extracted from leaves. This change in leaf chemical composition probably was caused by seasonal changes in environmental variables that stress floodplain vegetation.

\section{Community metabolism}

Characteristics of floodplain environments alternate between lentic and lotic depending on time of year. In tributaries of the Amazon and Orinoco rivers, heterotrophic and autotrophic biomass, production, and respiration are greatest under conditions of low through-flow (Reynolds et al. 1991, Vegas-Vilarrubia and Herrera 1993a, b, Reynolds and Descey 1996, Castillo 2000). Accumulation of biomass during times of low through-flow results in greater rates of production and respiration. On the other hand, when through-flow is high, biomass, production, and respiration are reduced, presumably because of losses of biomass via system flushing. In some parts of the Amazon River system, exceptions to the general trend of high production and respiration during low through-flow occur when lakes and lagoons become turbid during low-water periods (Melack and Forsberg 2001).

In our study area, standing autotrophic biomass, primary production, and community respiration were highest in the lagoon during the low-water period when the lagoon was mostly lentic. The maximum values for water-column autotrophic biomass and production in our study were typical of values reported for many lakes and lagoons from the Amazon system (Melack and Forsberg 2001), but they were low when compared to tropical lakes and lagoons around the world (Kaul 1985). Our values for water-column community respiration were consistent with those reported for areas of the Amazon River (Benner et al. 1995, Amon and Benner 1996a).

Floodplain lakes, lagoons, and rivers in the Amazon and Orinoco systems usually are assumed to be net heterotrophic (ratio of primary production to community respiration $[P / R]<1$ ) because a large quantity of allochthonous $\mathrm{C}$ enters the river systems from neighboring terrestrial environments (Wissmar et al. 1981, Melack and Fisher 1983, Richey et al. 1988, Junk et al. 1989, Devol and Hedges 2001). This assumption has been supported by direct measurements in the Orinoco River system (Vegas-Vilarrubia and Herrera 1993a, b) and indirect measurements in several temperate river systems (Kempe et al. 1991, Raymond et al. 1997). Net heterotrophy was found consistently in these systems, even in surface waters, where light was not limiting autotrophs (Quay et al. 1995).

However, some systems are net autotrophic. For example, $\mathrm{P} / \mathrm{R}$ increased to values $>1$ in a tributary to the Orinoco when the system became more lentic 
(Vegas-Vilarribia and Herrera 1993a, b). In our study area, nearshore $\mathrm{P} / \mathrm{R}$ was always $>1$, regardless of location (lagoon vs river) or hydroperiod (low-water vs falling-water). Net autotrophy is particularly important when phytoplankton are involved because algal production is more labile than allochthonous $\mathrm{C}$ sources, contains more energy per unit biomass, and frequently is preferred by consumers (Thorp and Delong 2002). In the Orinoco River system, stable isotope studies indicated that organic $\mathrm{C}$ originating from phytoplankton and benthic algae was the ultimate source of $C$ for most fish and invertebrates, even though this $C$ pool represented only a fraction of the available organic C in the system (Lewis 1988, Lewis et al. 1990, Hamilton et al. 1992, Lewis et al. 2001). Our measurements did not extend into deeper waters where light would not have reached the benthos, but we can conclude that at least the nearshore environments of this system, both lagoons and river, were net autotrophic during low-water and falling-water periods (Cotner et al. 2006). Future studies that incorporate lagoon and river bathymetry are needed to evaluate $P / R$ at the system level.

\section{Limitations on primary production}

DIN seemed more likely than SRP to become limiting to primary production based on the low DIN/SRP molar ratio. At times, DIN concentrations were low enough $(<0.1 \mu \mathrm{M})$ to be considered limiting, but at other times, DIN was above the level regarded as limiting $(>0.5 \mu \mathrm{M})$ in other systems (see Sommer 1989, Roelke et al. 1997, 2004). Diatoms should have been nutrient limited in the river during the fallingwater period when $\mathrm{SiO}_{3}$ concentrations were $<10 \mu \mathrm{M}$.

Benthic and water-column primary production were of similar magnitudes. This finding is contrary to data compiled from many tropical river systems in which phytoplankton contribute a very small proportion of primary production in associated lakes and lagoons (Junk 1985, Kaul 1985, Bayley and Petrere 1989, Melack and Forsberg 2001). Our results underscore the importance of phytoplankton in our study system. The similarity between benthic and water-column primary production in our study area may have been a consequence of strong grazer control of accumulated biomass in the benthos (Winemiller et al. 2006), a limiting factor that also has been observed in systems characterized by coarser substrates (Flecker and Taylor 2004). Additional studies are needed to better deduce other factors, such as high concentrations of tannins and protozoan grazing, that might affect watercolumn production and accumulation of biomass.

In summary, our results indicate that the leaves falling from the gallery forest surrounding the river channel and lagoon are a direct and significant source of organic $C$ in this section of the Cinaruco River, and this source of $C$ probably helps sustain the biomass at higher trophic levels. During the falling-water period, another undetermined organic C source was apparent, but only in the river. Unlike many tropical river systems, our nearshore study area in the Cinaruco River was net autotrophic, and autotrophic biomass and primary production in the benthos and the water column were similar. Together, these findings suggest that autochthonous $\mathrm{C}$ might be important in supporting biomass at higher trophic levels.

\section{Acknowledgements}

We are grateful to Paula Coble and members of her laboratory for doing the fluorometric and absorption analyses for our study. This research was supported, in part, by the National Science Foundation Ecology Program, award number DEB-0089834, and a Research and Education for Undergraduates supplement, award number DEB-0107456.

\section{Literature Cited}

Amon, R. M. W., AND R. BENNER. 1996a. Bacterial utilization of different size classes of dissolved organic matter. Limnology and Oceanography 41:41-51.

Amon, R. M. W., AND R. BENNER. 1996b. Photochemical and microbial consumption of dissolved organic carbon and dissolved oxygen in the Amazon River system. Geochimica et Cosmochimica Acta 60:1783-1792.

apHA (American Public Health Association). 1998. Standard methods for the examination of water and wastewater. $20^{\text {th }}$ edition. American Public Health Association, American Waterworks Association, and Water Environment Federation, Washington, DC.

Araujo-Lima, C. A. R. M., B. R. Forsberg, R. Victoria, and L. A. Martinelli. 1986. Energy sources for detrivorous fishes in the Amazon. Science 234:1256-1258.

Arrington, D. A., K. O. Winemiller, W. F. Loftus, And S. Akin. 2002. How often do fishes "run on empty"? Ecology 83: 2145-2151.

Barrios, E., AND R. Herrera. 1994. Nitrogen cycling in a Venezuelan tropical seasonally flooded forest: soil nitrogen mineralization and nitrification. Journal of Tropical Ecology 10:399-416.

BATTIN, T. J. 1998. Dissolved organic matter and its optical properties in a blackwater tributary of the upper Orinoco River, Venezuela. Organic Geochemistry 28:561-569.

Bayley, P. B., And M. Petrere. 1989. Amazon fisheries: assessment methods, current status and management options. Pages 385-398 in D. P. Dodge (editor). Proceedings of the International Large River Symposium (LARS). Canadian Special Publication of Fisheries and Aquatic Sciences 106. 
Benner, R., S. Opsahl, G. Chin-Leo, J. E. Richey, and B. R. FORSBERG. 1995. Bacterial carbon metabolism in the Amazon River system. Limnology and Oceanography 40:1262-1270.

Cammack, W. K. L., J. KalfF, Y. T. Prairie, and E. M. Smith. 2004. Fluorescent dissolved organic matter in lakes: relationships with heterotrophic metabolism. Limnology and Oceanography 49:2034-2045.

Carder, K. L., R. G. Steward, G. R. Harvey, and P. B. Ortner. 1989. Marine humic and fulvic acids: their effect on remote sensing of ocean chlorophyll. Limnology and Oceanography 34:68-81.

CAstillo, M. M. 2000. Influence of hydrological seasonality on bacterioplankton in two neotropical floodplain lakes. Hydrobiologia 437:57-69.

Castillo, M. M., G. W. Kling, and J. D. Allan. 2003. Bottomup controls on bacterial production in tropical lowland rivers. Limnology and Oceanography 48:1466-1475.

Coble, P. G. 1996. Characterization of marine and terrestrial DOM in seawater using excitation-emission matrix spectroscopy. Marine Chemistry 52:325-346.

Coble, P. G., S. A. Green, N. V. Blough, and R. B. Gagosian. 1990. Characterization of dissolved organic matter in the Black Sea by fluorescence spectroscopy. Nature 348:432435.

Coble, P. G., C. A. Schultz, ANd K. Mopper. 1993. Fluorescence contouring analysis of DOC intercalibration experiment samples: a comparison of techniques. Marine Chemistry 41:173-178.

Cotner, J. B., J. V. Montoya, D. L. Roelke, and K. O. WINEMILLER. 2006. Seasonally variable riverine production in the Venezuelan llanos. Journal of the North American Benthological Society 25:171-184.

Davis, S. E., C. Corronado-Molina, D. L. Childers, AND J. W. DAY. 2003. Temporally dependent C, N, and P dynamics associated with the decay of Rhizophora mangle L. leaf litter in an oligotrophic South Florida estuary. Aquatic Botany 75:199-215.

Devol, A. H., And J. I. Hedges. 2001. Organic matter and nutrients in the mainstem Amazon River. Pages 275-306 in M. E. McClain, R. L. Victoria, and J. E. Richey (editors). The biogeochemistry of the Amazon basin. Oxford University Press, New York.

Ertel, J. R., J. I. Hedges, A. H. Devol, J. E. Richey, and M. N. G. Ribero. 1986. Dissolved humic substances of the Amazon River system. Limnology and Oceanography 31:739-754.

Fejes, E. M., D. L. Roelke, G. Gable, J. L. Heilman, K. J. McInNes, AND D. A. Zuberer. 2005. Microalgal productivity, community composition, and pelagic food web dynamics in a sub-tropical, turbid salt marsh isolated from freshwater inflow. Estuaries 28:94-105.

FleCKer, A. S., AND B. W. TAYLOR. 2004. Tropical fishes as biological bulldozers: density effects on resource heterogeneity and species diversity. Ecology 85:2267-2278.

Forsberg, B. R., C. A. R. M. Araujo-Lima, L. A. Martinelli, R. Victoria, AND J. A. BonAssi. 1993. Autotrophic carbon sources for fish of the central Amazon. Ecology 74:643652.
Goulding, M. 1980. The fishes and the forest, explorations in Amazonian natural history. University of California Press, Berkeley, California.

Grasshoff, K., M. Ehrhardt, and K. Kremling, (editors). 1983. Methods of seawater analysis. $2^{\text {nd }}$ edition. VerlagChemie, Weinheim, Germany.

Hamilton, S. K., W. M. Lewis, JR., AND S. J. Sippel. 1992. Energy sources for aquatic animals in the Orinoco River floodplain: evidence from stable isotopes. Oecologia (Berlin) 89:324-330.

Hedges, J. I., G. L. Cowie, J. E. Richey, P. D. Quay, R. Benner, M. Strom, and B. R. Forsberg. 1994. Origins and processing of organic matter in the Amazon River as indicated by carbohydrates and aminoacids. Limnology and Oceanography 39:743-761.

Jordan, C. F. 1985. Nutrient cycling in tropical forest ecosystems. John Wiley and Sons, New York.

JunK, W. J. 1985. The Amazon floodplain-a sink or source of organic carbon. Mitteilungen aus dem GeologischePalaontologischen Institut der Universitat Hamburg. SCOPE/UNEP Sonderband 58:267-283.

Junk, W. J., P. B. Bayley, and R. E. Sparks. 1989. The flood pulse concept in river-floodplain systems. Pages 110-127 in D. P. Dodge (editor). Proceedings of the International Large River Symposium (LARS). Canadian Special Publication of Fisheries and Aquatic Sciences 106.

Kaul, V. 1985. Primary productivity of inland aquatic ecosystems under varying climate - a review. Tropical Ecology 26:164-178.

Kempe, S., M. Pettine, and G. Gauwet. 1991. Biogeochemistry of European rivers. Pages 169-212 in E. T. Degens, S. Kemp, and J. E. Richey (editors). Biogeochemistry of major world rivers. John Wiley and Sons, New York.

Klapper, L., D. M. McKnight, J. R. Fulton, E. L. Blunt-Harris, K. P. Nevin, D. P. Lovely, and P. G. Hatcher. 2002. Fulvic acid oxidation state detection using fluorescence spectroscopy. Environmental Science and Technology 36:31703175.

LEWIS, W. M., JR. 1988. Primary production in the Orinoco River. Ecology 69:679-692.

Lewis, W. M., JR., S. K. Hamilton, M. A. Rodríguez, J. F. SAUnders, III, AND M. A. Lasi. 2001. Foodweb analysis of the Orinoco floodplain based on production estimates and stable isotope data. Journal of the North American Benthological Society 20:241-254.

LeWis, W. M., JR., F. H. Weibezahn, J. F. SAunders, III, AND S. K. Hamilton. 1990. The Orinoco River as an ecological system. Interciencia 15:346-357.

McClain, M. E., J. E. Richey, And J. A. Brandes. 1997. Dissolved organic matter and terrestrial-lotic linkages in the central Amazon basin of Brazil. Global Biogeochemical Cycles 11:295-311.

Melack, J. M., AND T. R. FISHER. 1983. Diel oxygen variations and their ecological implications in Amazon floodplain lakes. Archiv für Hydrobiologie 98:422-442.

Melack, J. M., and B. R. Forsberg. 2001. Biogeochemistry of Amazon floodplain lakes and associated wetlands. Pages 235-274 in M. E. McClain, R. L. Victoria, and J. E. Richey 
(editors). The biogeochemistry of the Amazon basin. Oxford University Press, New York.

Montoya, J. V., D. L. Roelke, K. O. Winemiller, J. B. Cotner, AND J. A. SNIDER. 2006. Hydrological seasonality and benthic algal biomass in a Neotropical floodplain river. Journal of the North American Benthological Society $25: 157-170$.

Obernosterer, I., AND R. BenNer. 2004. Competition between biological and photochemical processes in the mineralization of dissolved organic carbon. Limnology and Oceanography 49:117-124.

Quay, P. D., D. O. Wilbur, J. E. Richey, A. H. Devol, R. Benner, AND B. R. Forsberg. 1995. The ${ }^{18} \mathrm{O}:{ }^{16} \mathrm{O}$ of dissolved oxygen in rivers and lakes in the Amazon Basin: determining the ratio of respiration to photosynthesis rates in freshwaters. Limnology and Oceanography 40: 718-729.

Ramia, M. 1967. Tipos de savana en los Llanos de Venezuela. Boletin de la sociedad Venezolana de Ciencias Naturales 28:264-288.

Raymond, P. A., N. F. Caraco, And J. J. Cole. 1997. $\mathrm{CO}_{2}$ concentration and atmospheric flux in the Hudson River. Estuaries 20:381-390.

Reynolds, C. S., P. A. Carling, and K. Beven. 1991. Flow in river channels: new insights in hydraulic retention. Archiv für Hydrobiologie 121:171-179.

Reynolds, C. S., And J. P. Descey. 1996. The production, biomass and structure of phytoplankton in large rivers. Archiv für Hydrobiologie Supplement 113:161-187.

Richey, J. E., A. H. Devol, S. C. Wofsy, R. Victoria, and M. N. G. Ribeiro. 1988. Biogenic gases and the oxidation and reduction of carbon in the Amazon River and floodplain waters. Limnology and Oceanography 33:551-561.

Roelke, D. L., Y. Buyukates, M. Williams, and J. Jean. 2004. Interannual variability in the seasonal plankton succession of a shallow, warm-water lake. Hydrobiologia 513: 205-218.

Roelke, D. L., L. A. Cifuentes, And P. M. Eldridge. 1997. Nutrient and phytoplankton dynamics in a sewage impacted gulf coast estuary: a field test of the PEGmodel and Equilibrium Resource Competition theory. Estuaries 20:725-742.

SOMMER, U. 1989. The role of competition for resources in phytoplankton succession. Pages 57-106 in U. Sommer (editor). Plankton ecology. Springer-Verlag, Berlin, Germany.

Thorp, J. H., AND M. D. Delong. 2002. Dominance of autochthonous autotrophic carbon in food webs of heterotrophic rivers. Oikos 96:543-550.

TRотн, R. G. 1979. Vegetational types on a ranch in the central Llanos of Venezuela. Pages 17-30 in J. F. Eisenberg (editor). Vertebrate ecology in the Northern Neotropics. Smithsonian Institution, Washington, DC.

Vegas-Vilarrubia, T., AND R. Herrera. 1993a. Effects of periodic flooding on the water chemistry and primary production of the Mapire system (Venezuela). Hydrobiologia 262:31-42.

Vegas-Vilarrubia, T., AND R. Herrera. 1993b. Seasonal alternation of lentic/lotic conditions in the Mapire system, a tropical floodplain lake in Venezuela. Hydrobiologia 262:43-55.

VitouseK, P. M. 1982. Nutrient cycling and nutrient use efficiency. American Naturalist 119:553-572.

VitouseK, P. M. 1984. Litterfall, nutrient cycling and nutrient limitation in tropical forest. Ecology 65:285-298.

WAICHMAN, A. V. 1996. Autotrophic carbon sources for heterotrophic bacterioplankton in a floodplain lake of central Amazon. Hydrobiologia 341:27-36.

Wetzel, R. G. 2001. Limnology. $3^{\text {rd }}$ edition. Academic Press, New York.

WetZel, R. G., AND G. E. LiKENS. 1991. Limnological analysis. $2^{\text {nd }}$ edition. Springer-Verlag, New York.

Winemiller, K. O., AND D. B. JePSEN. 1998. Effects of seasonality and fish movement on tropical river foodwebs. Journal of Fish Biology Supplement A 53:267-296.

Winemiller, K. O., AND D. B. JePSEN. 2004. Migratory neotropical fishes subsidize food webs of oligotrophic blackwater rivers. Pages 115-132 in G. A. Polis, M. E. Power, and G. R. Huxel (editors). Food webs at the landscape level. University of Chicago Press, Chicago, Illinois.

Winemiller, K. O., J. V. Montoya, D. L. Roelke, C. A. Layman, AND J. B. CotNER. 2006. Seasonally varying impact of detritivorous fishes on the benthic ecology of a tropical floodplain river. Journal of the North American Benthological Society 25:250-262.

Wissmar, R. C., J. E. Richey, R. F. Stallard, AND J. M. Edmond. 1981. Plankton metabolism and carbon processes in the Amazon River, its tributaries and floodplain waters. Ecology 62:1622-1633.

Received: 15 October 2004 Accepted: 17 August 2005 